\title{
The Helen Files
}

\section{Anita Dubey}

This spotlight on the "Three Helens" might be called "Style and Substance". Each brought a significant contribution to the development of nursing in Canada over a substantial part of the 20th century. In the case of Dr. Helen Mussallem, that contribution continues. However, while these short biographies provide a snapshot of their leadership, they do not capture their style. In 1989, some 27 years after she became director of the School of Nursing, Dr. Carpenter was invited to have her portrait taken to hang in the Nursing building at the University of Toronto, she grumbled good naturedly, "You should have your picture taken the day you become director, because you're never going to look that good again!"

These women had much in common: doctoral degrees from Teachers College at Columbia University years before that became the norm, senior roles in institutions of influence in nursing, vision about what nursing's contribution to health in Canada should be, and style. They dressed elegantly. They spoke eloquently. Style on its own might be considered trivial but when paired with the ability to clearly articulate positions and policy, it makes a notable contribution. The Canadian Journal of Nursing Leadership salutes the "Three Elegant Helens" and asks, "Who will be the Helens of the 21st century?"

\section{- Dot Pringle, Editor-in-Chief}

The Canadian nursing profession has been fortunate to have three strong advocates for nursing education from the 1960s onwards, an era of tremendous change in the way nurses were trained. The women share similarities most coincidentally, in their names, as all are called Helen (one of the most popular girl's names in the first decades of the 1900s). All three, who have PhDs, held leadership roles in nursing associa- tions or academic institutions, as well as contributing to nursing internationally. The Canadian Journal of Nursing Leadership is pleased to highlight the contributions of Helen Carpenter, Helen Mussallem and Helen Glass. Through these profiles, we aim to present a picture of how they influenced nursing education in Canada during a period of change, while also highlighting their unique achievements. 


\section{Helen Carpenter}

Helen Carpenter was born in Montreal in March 1912, the youngest of four children. Her parents stressed the importance of education early, and encouraged all their children to go to university. That message had a strong influence on Carpenter's life, prompting her to pursue higher studies in nursing outside the country. This eventually enabled her to create opportunities for others to obtain graduate nursing education in Canada and even influence the course of nursing education in a country halfway around the world.

"She had a deep interest in nursing education, and in quality education," says Phyllis Jones, professor emeritus at the University of Toronto, who worked with Carpenter. "I admired her work and what she stood for, and her drive in pursuing that."

Carpenter began her studies at $\mathrm{U}$ of $\mathrm{T}$, earning an $\mathrm{RN}$ and diploma in nursing. After graduating, she became a public health nurse, working in diverse locations including an Ontario outpost hospital, the Victorian Order of Nurses, the British Columbia Department of Health and the East York Department of Health.

But a desire for further education drew her back to university. As bachelor's degrees in nursing were not offered in Canada at the time, she went to Columbia University in New York to complete a bachelor of science in 1943. Following that, she took a master's degree in public health at Johns Hopkins University in Baltimore, Maryland in 1945.

Upon her return to Canada, Carpenter joined academic life in the

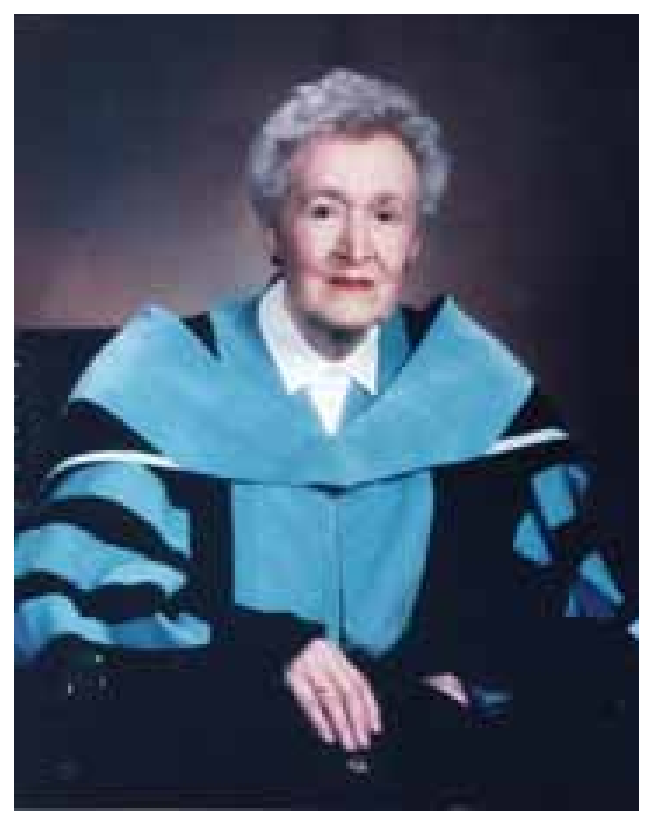

“It's due to Helen's work that we had a graduate program in Toronto."

Faculty of Nursing at the University of Toronto. She rose to hold the position of dean from 1962 to 1972. During that time, she also obtained her doctorate from Columbia University.

"She was rather quiet and determined. She got things done and influenced things that way," says Kathleen King, who worked with Carpenter for many years at the University of Toronto. Part of Carpenter's success was her ability to work with a range of colleagues in both the community and the university, alongside people with diverse backgrounds.

"She was able to draw people together and arrive at a consensus over issues," says Jones.

"It's due to Helen's work that we had a graduate program in Toronto," says King. At a time when graduate education in nursing was in the devel- 
opmental phase, Carpenter was able to convince the university's graduate program of the importance of graduate nursing education, says Jones. This development was significant for both the faculty and for nursing education in Canada. Carpenter then chaired the graduate department from 1972 to 1976, before retiring.

"She was an extremely kind, supportive person," says King. As a supervisor, she says Carpenter gave her staff independence to try things, and took pleasure from others' successes.

Outside the university, Carpenter served as president of the Canadian Nurses Association from 1960 to 1962. She received many awards in recognition of her leadership, including fellowships from the Rockefeller Foundation and the Canadian Red Cross.

Carpenter also served as a World Health Organization consultant for a study on nursing education in New Zealand. The 1971 report from this study, "the Carpenter report," led to the phasing out of hospital-based training for nurses in favour of training as part of the general education system. The report is still recognized as a benchmark in the development of nursing education in New Zealand.

Carpenter was affectionately known as "Auntie Helen" by a wide circle of nieces and nephews, her "adopted" nieces and nephews and their children, to whom she passed on her love of education.

Helen Carpenter passed away in December 2003 in Toronto, at the age of 91 .

\section{Helen Mussallem}

The first public health nurses in British Columbia worked in the area around Maple Ridge, where Helen Mussallem grew up. The fact that they were held in high regard, plus the appeal of nursing over other professions available to young women in the 1930s, drew Mussallem to study nursing at the Vancouver General Hospital Nursing School.

It was the start of a career that would lead to major changes in the way nursing education was delivered in Canada, as well as advancing the role of nursing in other countries.

After earning her diploma in 1937, she worked for six years in the operating room at Vancouver General. She then joined the Nursing Sisters in 1943, serving with Royal Canadian Army Medical Corps in war-battered Europe. It was a challenging and eye-opening experience. Back in Canada, she used credits through her army work to return to school and took a bachelor's degree in nursing from McGill University in Montreal.

"I always had a desire to learn, to do things better, to improve public health," says Mussallem. She returned to work at Vancouver General Hospital, eventually becoming its director of nursing education and later earning a master's degree in nursing from Columbia University in New York.

By 1957 , she had already had a rich and eventful career, but things were about to become more interesting. The Canadian Nurses Association (CNA) asked Mussallem to conduct a survey of nursing schools across Canada. The goal was to assess how prepared the 


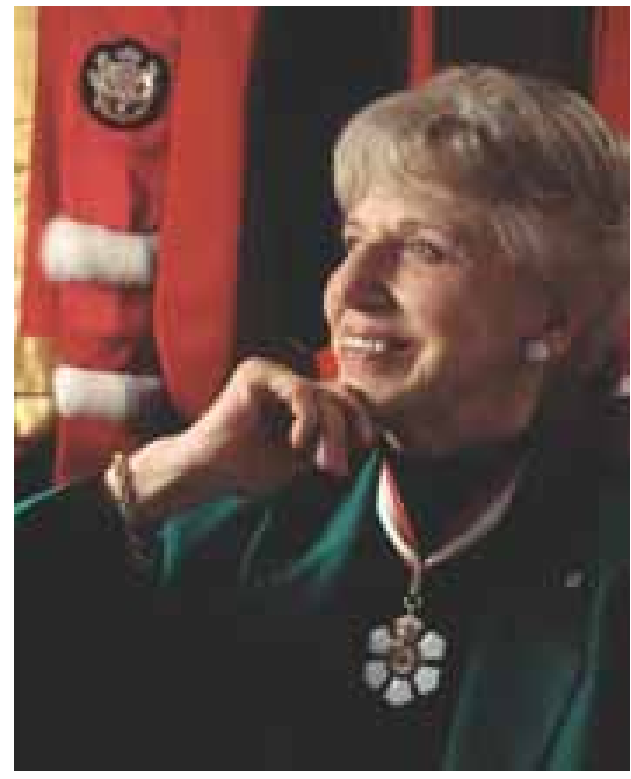

"If you think of Canadian nursing, there are few leaders who have influenced the course of health policy as she did."

schools were for a national system of accreditation.

Mussallem did a coast-to-coast trip across Canada, studying the systems in place at 25 nursing schools. "Travelling was not much fun in those days," she says. "I used varied and miserable modes of travel. I just smiled and went on."

Her report, Spotlight on Nursing Education, published in 1960, highlighted the shortcomings of the system. She discovered that in hospital-based schools of the time, nurses in training were essentially used as "indentured labour."

"The report helped to focus on nursing education," says Ginette Rodger, former executive director and past president of the CNA, who was a board member when Mussallem was executive director.
Powerful associations, such as the Canadian Hospital Association and Canadian Medical Association, were not pleased with Mussallem's criticism of established method of nurse training. The CNA, however, supported Mussallem and hired her to implement her report, which eventually changed the course of nursing education in Canada.

During a visit to New York, a former professor encouraged Mussallem to work on a doctorate. "She knew me well enough to know it was good for me," says Mussallem. In 1962, she became the first Canadian nurse to earn a $\mathrm{PhD}$ in nursing.

The following year, she became executive director of the CNA. In that role, she served on the Royal Commission on healthcare, bringing nurses for the first time to the health policy table. She also wanted to push the community health aspect of nursing. In addition, she developed and strengthened networks with other organizations, such as the Canadian Medical Association and the Canadian Public Health Association, says Rodger. She also created an excellent library at the CNA, which is now named after her.

"Her leadership is recognized in all quarters," says Rodger, who is currently chief of nursing at the Ottawa Hospital, University of Ottawa Heart Institute and the Rehabilitation Centre.

Mussallem has also served vital roles on the international scene, both as a consultant and also in convincing the Canadian International Development Agency (CIDA) to give money to nurses to undertake international projects, said Rodger. 
"I found excitement and satisfaction in international work - I felt I could really make an impact," says Mussallem. She was the first Canadian nurse to go to Cuba to help with their nursing education system in 1962 and maintained a long working relationship with colleagues there, even meeting Fidel Castro twice. She has also helped establish national nursing associations in several African countries. And, she recounts, she almost got killed doing work for the World Health Organization in Montevideo, Uruguay. One evening she went out for a walk, having not heard radio warnings that people had to stay inside after curfew or risk being shot.

"She's extremely intelligent, down to earth, and way ahead of her time," says Elizabeth Crawley, material resources manager at the CNA, who worked for Mussallem in the 1970s.

In recognition for her work, she has been made an Officer of the Order of Canada, among numerous other awards. Based in Ottawa, she continues to serve on 23 boards, and is particularly proud of her work with the Victorian Order of Nurses.

"If you think of Canadian nursing, there are few leaders who have influenced the course of health policy as she did. She has dedicated her professional life to nursing. We owe her a great debt of gratitude," says Rodger.

\section{Helen Glass}

Helen Glass's career could have gone in another direction, as she began studying nutrition in Saskatoon. However, after a year she realized the program wasn't a good fit. Partly inspired by an aunt who was a nurse, she went off with a friend to study at the Royal Victoria Hospital School of Nursing in Montreal, earning her diploma in 1939.

Nursing suited her, and Glass has become a key advocate for nursing research, advanced nursing education and promotion of nurses' role in primary healthcare. And her efforts have all had tangible results.

In her early career, during the war years, Glass worked as a nurse in Ontario, British Columbia and Saskatchewan, in places her husband was posted as a flight instructor with the Royal Canadian Air Force. In 1959, recognizing the importance of further education, she moved to the United States to pursue bachelor's and master's degrees. She brought her teenaged daughter to live with her, and completed her degrees in nursing education from Columbia University in New York. After returning to Canada, her career at the University of Manitoba's School of Nursing in Winnipeg began in 1962, and she gradually rose up the ranks of professorship.

"I wanted to get into doctoral work, and kept pushing on," she says. "There was 10 years between my master's and doctorate." She returned to Columbia University to complete her doctorate in 1971, specializing in graduate education instruction.

She became director of the University of Manitoba's school between 1972 to 1979.

"What I noticed early was that she looked at the broader perspective, not just her own perspective. And she was fun," says Kay Arpin, who did a term 
with Glass at Columbia University in the 1970s.

She held the view that nurses have a fundamental basic role in preventing illness and promoting good health, and taught this view to students. She also helped develop the faculty, bringing broader national and international recognition, says Arpin. Glass also felt it was important to engage nursing students in the political process.

Glass set the groundwork for the development of the Manitoba Nursing Research Institute, which opened in 1985. "I was pushing for scientifically based care. We did things in nursing but didn't know if they were effective," she says. In her push to promote evidencebased nursing practice, "she was really blazing the trail and being a pioneer," says Arpin.

Glass also proposed the development of a graduate program in nursing, and after serving as director, she worked as program coordinator until 1985.

From 1980 to 1985, she also served as a research consultant to the World Health Organization and Danish Institute of Health and Nursing Research in Copenhagen. It was the largest international nursing study conducted at that point, involving 11 countries in 10 languages. The project looked at nursing care needs in the elderly and in patients who had elective surgery.

Among her numerous awards and honorary degrees, she says she is most proud of receiving the Officer of the Order of Canada in 1989. As well, a new nursing education and research facility at the university, which opened in 2000,

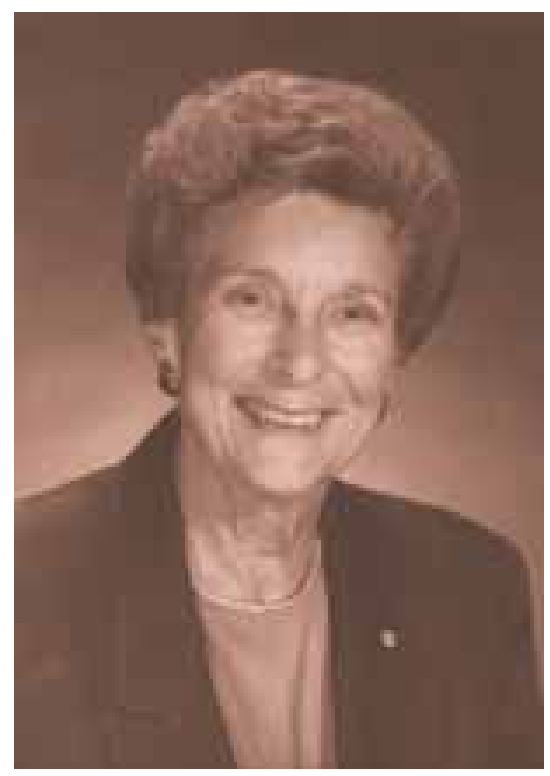

"I saw things to do and did them. I wanted nursing to achieve new directions."

was named the Helen Glass Centre for Nursing in her honour.

In addition to decades of involvement with the Manitoba Association of Registered Nurses and the Canadian Nurses Association - she served as president from 1982 to 1984 - she was also involved with the International Council of Nurses in executive positions for several years.

"I saw things to do and did them. I wanted nursing to achieve new directions," she says of her career.

"My students are all over the world, and many are taking leading roles in primary healthcare where there had never been that type of role," she adds. "It's wonderful when they come back and tell me what they're doing. That's tremendously satisfying." Researched and written by Anita Dubey. 